\title{
HUMAN RIGHTS AND JUDICIAL DIALOGUE BETWEEN AMERICA AND EUROPE: TOWARD A NEW MODEL OF LAW?
}

\author{
FRANCISCO JAVIER ANSUÁTEGUI ROIG*
}

\begin{abstract}
In a context of progressive deterritorialization, the analysis of the judicial dialogue has certain profits when reformulating some aspects of a particular way of understanding the law, characterized by the principle of territoriality and by a theory of the sources of law in which the judge has a clearly secondary position in relation to the legislature and in which the sources are relevant since they are understood as explicit expression of a will. This paper describes the operability of the dialogue between the Inter-American Court of Human Rights and the European Court of Human Rights which, horizontally and voluntarily, can help create a context of community in relation to the contents of human rights, based on the recognition of the value of judicial arguments and the judge's self-understanding as members of a hermeneutical community.
\end{abstract}

Keywords: Judicial Dialogue, Deterritorialization, Epistemic Community, Judicial Comity.

Summary: I. PREAMBLE; II. CONTEXT OF THE REFLECTION ON JUDICIAL DIALOGUE ABOUT RIGHTS: GLOBALIZATION AND DETERRITORIALIZATION OF LAW; III. AN APPROACH TO THE CHARACTERIZATION AND THE TYPOLOGY OF THE JUDICIAL DIALOGUE; IV. JUDICIAL DIALOGUE ON HUMAN RIGHTS BETWEEN AMERICA AND EUROPE; V. JUDICIAL DIALOGUE AND MODEL OF LAW.

\section{PREAMble}

The aim of this contribution is to emphasize the importance of the dialogue between the Inter-American Court of Human Rights (IACHR) and the European Court of Human Rights (ECHR) in order to reformulate some aspects of a particular way of understanding the law, characterized by the principle of territoriality and by a theory of the sources of law in which the judge has a clearly secondary position in relation to the legislature and in which sources are relevant since they are understood as explicit expression of will.

Nowadays, legal knowledge is less and less compartmentalized and the traditional borders and distinctions (identified with branches of law) often have a purely administrative significance. However, everyone is somehow conditioned by training and by ordinary prospects. This is to justify the fact that the viewpoint of this paper is not

\footnotetext{
* Professor of Philosophy of Law. Instituto de Derechos Humanos "Bartolomé de Las Casas", Universidad Carlos III de Madrid, Spain (javofil@der-pu.uc3m.es).
} 
necessarily coincident with the characteristic one of Constitutional law or International law scholars, for example. I think that from the point of view of the Philosophy of Law (or, to be more specific, the Theory of Law) the analysis of judicial dialogue, and particularly dialogue between the IACHR and the ECHR, let us consider some consequences which go beyond the dialogue itself, and which have to do with certain essential questions of Theory of Law.

Indeed, I believe that the judicial dialogue has consequences that affect the relationship between law and power. So, we are in an area where the judgment of a court "strange" to the system is taken into account when making the decision, not because it has been pronounced by a competent authority and is a part of the system of sources for which the court is required, but because of the quality, reasonability or prestige of the other court; and as a consequence, the fact that the law comes solely from the will of the appropriate authority in the legal system of reference is no longer an essential element of the theory of normative creation. The criterion of validity no longer has to do with competence (understood as enabled by another norm) of the authority, but with the argumentative quality of the content of the decision.

Moreover, the judicial dialogue draws attention to the classic question of the position of jurisprudence in the system of sources. In this case, we are not thinking of jurisprudence from an intrasystemic viewpoint but stressing the importance of the "external" jurisprudence as a mechanism of integration, of heterocomposition of the legal system.

To this should be added that the judicial dialogue is by no means the only case of exchange, of communication between legal systems or models. In a world where the conditions to which human communication has been subjected for centuries tend to disappear, the legal and doctrinal fields are also scenarios in which the legal dialogue occurs today.

\section{CONTEXT OF THE REFLECTION ON JUDICIAL DIALOGUE ABOUT RIGHTS: GLOBALIZATION AND DETERRITORIALIZATION OF LAW}

I think that any reflection on the judicial dialogue, beyond the required specification of what we are talking about, must begin with an effort of characterization of the legal context in which this dialogue takes place; and which at the same time facilitates such a dialogue. In this regard, I want to emphasize here some dimensions which, while not depleting the scenario on which today judicial dialogue occurs, can help us understand its meaning. Thus, I will make a brief reference to two dimensions, certainly interlinked: globalization and deterritorialization of law.

The effects of globalization have been approached from very different perspectives. One of those perspectives is the legal one. For the law, globalization means, among other things, the emergence of new dimensions that require regulation, and also the generation of dynamics involving the transformation of consolidated 
structures and new ways of thinking. I will not explain the various relevant aspects of globalization for the law, abundantly covered by the doctrine ${ }^{1}$. In any case, the disruption of traditional spatiotemporal conditions that have shaped human action, and which constitutes one of the basic aspects of globalization, no doubt, has consequences that affect the legal discourse.

The discourse claiming a direct link between globalization and universality of rights is common. Regardless of whether the mere assertion of this relationship deserves a critical analysis (recall the question by Stefano Rodotà: "Globalization through the market or through the rights"? (RODOTÀ 2014: 75)) in any case, it is true that globalization can help in deepening the discourse on the universality of rights. How? By identifying common problems, from the knowledge of the circumstances of the other, causing joint and shared legal structures and efforts to address these problems, which are considered of everyone, and providing answers or possible solutions that can also be shared. From this point of view, globalization can be a contributing element of the requirements of the universality of rights, but not their necessary guarantee.

Identifying common problems concerning the rights already implies, somehow, the existence of a common and shared discourse -although containing minimum requirements-regarding its foundation. And in the creation and articulation of shared legal structures, certainly the judge plays a very important role. As recalled by Sabino Cassese from a more general perspective, beyond the States, there are no governments or parliaments, but there are judges and courts (CASSSE 2009: 4).

To this it should be added that among the dynamics of globalization that affect traditional modes of legal thought, are those which require us to rethink the relationship between law and space, between law and territory. Consideration of the territory, as an area of validity, as the space which determined the relevance of the issues in which law could be applied -and the competent authority behind it- ultimately the consideration of the state territory as the framework of sovereignty, has been basic in the selfunderstanding of modern law. And it has conditioned the development of international law and international relations considered as relations among subjects which reserved a domain area consisting, initially, in the territory. The presence in a given territory determined the submission to a state jurisdiction in a certain field of subject-matters.

But this story, surely, no longer serves us as a whole. I am afraid that in many cases it will continue being worthwhile as an interpretive key for given situations, but in any case it is certain that it does not explain the sense of the dynamics that have to do with globalization and that imply the reformulation of the relationship between law and (state) territory.

In this sense, Maria Rosaria Ferrarese has characterized modern law as a limitless law (Diritto sconfinato), highlighting the loss of the necessary and exclusive

\footnotetext{
${ }^{1}$ For a recent example, see RUIZ MIGUEL (2014). From a more general point of view, see (2000). In Spanish, by the same author, see TWINING (2003). Also GALGANO (2005).
} 
link between the law and the territorial dimension. Indeed, the disruption of this relationship can be performed in different ways. It is possible a hard sconfinamento, whose main manifestation would be war, as the highest expression of conflict and which means rewriting the limits of the boundaries in their geographical and political dimension. But it is also possible a soft sconfinamento, whose language is not military at least from a traditional point of view; it is the language of technology, economy, or that of the community around a universalist ethics. Thus, the transition from a hard mode to a soft implies a progressive irrelevance of the political boundaries of states, with a progressive loss of importance also of territoriality (FERRARESE 2006: 12). Thus, the law is no longer necessarily linked to the state territory; the legality initiates new development. But it is important to point out an idea here: while overcoming the necessary link between law and state territory means a loss of political density of legal decisions that occur in the new areas -since political will, linked to the will of the majorities in Rousseauian terms, is not as easily identifiable after the decision-makingit does not mean that we are in the realm of the irrelevant. The position that the law of rights has in the process of deterritorialization is a good example of this. Thus, we would pass from a law which is directly linked to a political will, to a law "to do things", which is intended to achieve goals and objectives: "The teleological and instrumental inclination of the law is clearly in detriment of that legislative discretion that was the typical feature of state law: the "omnipotence of the legislature" yields to the functionality” (FERRARESE 2006: 22).

Therefore, the process of "sconfinamento" of the law allows us speaking of "sconfinati" rights in a double sense. On the one hand, because a breach of the rightsstate territory relationship, according to which, rights were an exclusive matter of the state. On the other, because the fact that there is also a "sconfinatezza" of their content and scope which, depending on the requirements of their universality, presents them as a kind of "untouchable essence of human beings that identifies the area of what is permitted” (FERRARESE 2006: 103).

The split of the rigid connection between law and (state) territory has the meaning of an opening process. Our time shows us, in terms of Gustavo Zagrebelsky, the "impotence of the closed constitutional law" and the trend towards an open constitutional law (ZAGREBELSKY 2008a: 386 ff.). I believe that although Zagrebelsky's reflection refers to the lines of evolution of constitutional law in Europe, its meaning transcends this area. Thus, this overcoming of the connection territory-law implies the correlative overcoming of a "constitutional particularism" linked to the reduction of all the law to the sovereign parliamentary act; and a statement that what is relevant to the law is what is internal to the scope of the sovereignty and the consequent affirmation of the irrelevance of all that is external (ZAGREBELSKY 2008a: 388).

But globalization invites -and obliges- us to "look beyond" (ZAGREBELSKY 2008b: 261), in a process in which the distant ends up acquiring relevance in our daily development. In an understanding of globalization as "a condition by which distant events, through causal coordinates of various kinds, produce consequences on the local 
protection of constitutional goods” (ZAGREBELSKY 2008a: 399) ${ }^{2}$, constitutional law exceeds, in a sense, the borders of the states and, from the horizontal connections provided by the open structure of the norms of fundamental rights, it is possible to identify a "ultra-state constitutional lowest common denominator". And, as we shall see, judges will have much prominence in identifying this shared heritage.

The judicial dialogue, in its various aspects (dialogue among different constitutional jurisdictions, between constitutional jurisdictions and supranational jurisdictions, or among supranational jurisdictions), is particularly relevant in the field of human rights, or fundamental rights. What can be the reason for this? I think there are several explanatory reasons in a context in which, as we have just seen, we are witnessing the gradual breakdown of the law-territory relationship. We can think of the relevance of rights as fundamental content, normative core of any legal system. But also in the fact that rights imply the existence of a shared normative core, which as such transcends state areas and which is presented as universal, which makes their arguments beyond those areas operate more easily. Moreover, the jurisdictions of rights are politically relevant, and these jurisdictions are called to "work" -at least tendentiouslyin democratic contexts (and democratic contexts are open contexts ...). I also think that in the concrete case of the dialogue between the IACHR and the ECHR, voluntariness and the horizontal nature of it is an element that enhances its operability.

Our understanding of rights is that of universal rights whose normative claims go beyond strict state control. Indeed, they are rights claiming ultra-state validity, on one hand; on the other, they are rights for which the state cannot claim exclusive competence over other instances or possibilities of control and protection. Therefore, the universality of rights is not only a question concerning the normative extension of moral claims. It also requires overcoming traditional state frames of reference, and also regional ones. That means that the jurisdiction of reference will not be exclusively the state's. This will have to live with other supranational, regional, universal jurisdiction, which also claim jurisdiction in guaranteeing rights. Note that we are talking about jurisdictions, i.e., mechanisms in which a neutral third party -the judge- intervenes to resolve a dispute from the application of existing rules.

Contemporary constitutionalism, which transcends state boundaries, has favored the position of judge in the defense of rights. This, on the other hand, as known, generates legal and political tensions within the systems of democratic constitutionalism ${ }^{3}$. These tensions are behind the critical reference to the existence of a genuine “juristocracy” (HIRSCHL 2004) or claim of a popular constitutionalism ${ }^{4}$ or a critical constitutionalism (DE CABO MARTIN 2014). But what matters here is to emphasize that this privileged role of the judge is still maintained when we stop thinking of state mechanisms and pay attention to supranational bodies. We are therefore facing a scenario in which there are different jurisdictional mechanisms

\footnotetext{
2 ZAGREBELSKY has also referred to the contribution of International Law to this opening or "dilation in the space of principles in current constitutionalism (see ZAGREBELSKY (2013)).

${ }^{3}$ I referred to this tension in ANSUATEGUI (2013a).

${ }^{4}$ See, among others, KRAMER (2004).
} 
intended to ensure rights. Therefore, jurisdictions referred to the substantive core of democratic systems. Substantive core of which universality is preached, which implies that the arguments in support will not be -should not be- local. In addition, we are thinking of normative arguments, rights, conceptually linked to democratic systems, which are presented as open systems, in antithesis to the closure that should characterize nondemocratic systems. This openness must be understood in reference to the neither particular nor exclusive sense of the arguments aimed at ensuring and consolidating systems of rights. But it also means an opening in regard to the recognition of the weight and validity of arguments and defense strategies generated in other instances, in the "beyond" of Zagrebelsky. In this regard, the judicial dialogue can be seen as a requirement of the universality of rights. At this point, taking seriously the universality of rights implies the recognition of the possible validity and enforceability of arguments and reasons generated in other jurisdictions where rights are also claimed. This is possible, as I point out, by the fact that the reasons for rights are not local reasons. Talk about universal rights presupposes to preach the existence of some kind of shared normative core. And from the moment that there are shared elements, the dialogue is possible; dialogue which implies, logically, the shared existence of arguments to dialogue about or at least a shared language. Otherwise it would be a "discovery"; or an imposition.

We have, then, some basic elements that generally allow us to understand the context of the judicial dialogue on rights: deterritorialization of law and rights; universality of rights; relevant position of the judge -not necessarily the state judge- in guaranteeing rights; open nature of rights systems.

\section{AN APPROACH TO THE CHARACTERIZATION AND THE TYPOLOGY OF THE JUDICIAL DIALOGUE}

As is well known, De Vergottini has approached critically the indiscriminate use of the notion of "judicial dialogue," noting that "the dialogue seems to have become one of the rhetorical fetishes that are evoked to hide comparative improvisations often lacking foundation and, in any case, scientifically inappropriate” ((DE VERGOTTINI 2010: 63). That is, the characterization of the judicial dialogue is not a peaceful issue. In this regard, the judicial dialogue should be differentiated from the unilateral quotation of precedents of a different legal system ((DE VERGOTTINI 2010: 175-186), or the comparison ((DE VERGOTTINI 2010: 233 ff. $)^{5}$, for example. Certainly a cautious approach, like that of De Vergottini, must be differentiated from that other consisting in the rejection of the use of legal arguments external to the legal system. Possibly one of the most representative and known cases is that of Justice Scalia in the dissenting opinion in the case Lawrence v. Texas ${ }^{6}$. On that occasion, the Supreme Court declared unconstitutional a Texas law criminalizing sodomy, and for that they cited English law and jurisprudence of the ECHR. Justice Scalia opposed the majority opinion stated by

\footnotetext{
${ }^{5}$ See too DE VERGOTTINI (2013: $481 \mathrm{ff}$.).

${ }^{6}$ Lawrence v. Texas, 539 US 558, 568-74 (2003)
} 
Justice Kennedy, favorable to the use of foreign law in the construction of argument and claimed the self-sufficient character of American law originally contained in the Constitution (TRIBE 2004: 1893 ff.) ${ }^{7}$. That is what Gustavo Zagrebelsky does not hesitate to describe as "constitutional chauvinism" (ZAGREBELSKY 2008a: $403 \mathrm{ff}$.) and Bruce Ackerman considers a "provincial particularism" which should be confronted with a good dose of pragmatism that involves identifying common problems and learning from the strategies employed in addressing these problems (ACKERMAN 1997: 794-797) ${ }^{8}$.

When we talk about judicial dialogue we are, as noted by Rafael Bustos, facing a scene of variable geometry in which the recognition of the subject and of the order with which there is a dialogue can derive from direct explicit norms, from indirect links, "or even from the peculiar position of the interpretive authority acquired over time by specific courts in the exercise of their functions" (BUSTOS GISBERT 2012: 35). A geometry that is variable according to the forms, the intensity, the perspective and the structure (BUSTOS GISBERT 2012: 19 ff.). Indeed, the transjudicial communication can take many forms. From the mere recognition of foreign court decisions (not explicitly mentioned) in national judgments to the migrations of constitutional ideas; in relation to the intensity, some have spoken of a communication "ad exemplum" (in those cases where foreign reference is cited to support their own decision or to highlight the inadequacies of it); or of a communication "a fortiori" when it comes to consolidate or strengthen the arguments built from the domestic law through reference to external arguments; communication "ad ostentationem" implies strengthening the argument with an erudite and/or abundant quotation, unlike a communication "ad auctoritatis", which involves the use of a jurisprudence to which authority is recognized to support decisions that are not easy to take with exclusive recourse to their own law. Finally, communication "ex lege" is the one imposed by the law itself.

Regarding the structure, it is possible to speak of vertical, semi-vertical, horizontal dialogues. Indeed, it is possible to think of relations between legal systems in a vertical sense -for example, between the law of the European Union and those of the member states, or between the law of the Council of Europe and those of the member states-; and horizontally: between different constitutional jurisdictions, or between various supranational systems (CASSESE 2009: $41 \mathrm{ff}$.). And depending on the degree of mutual involvement, Anne-Marie Slaughter has referred to direct dialogues, monologues and intermediate dialogues (SLAUGHTER 1994: 99 ff.).

In short, we are in a context in which the forms of "transjudicial communication” are varied, as are their functions too (SLAUGHTER 1994: 114 ff.); so,

\footnotetext{
7 The position of Justice Scalia can be consulted in his discussion with Justice Breyer in American University in January 2005, “A Conversation between U.S. Supreme Court Justices (The relevance of foreign legal materials in U.S. constitutional cases: A conversation between Justice Antonin Scalia and Justice Stephen Breyer)”, International Journal of Constitutional Law, 2005, n. 3 (4), p. 519 ff.

${ }^{8}$ Lucio PEGORARO has pointed out that the "narrow minded vision of the American originalist current (which in flagrant contradiction claims that the rights defended in his Constitution are "universal") is denied by the practice of numerous courts” (PEGORARO 2013: 65).
} 
we can think of an increase of the effectiveness of court decisions, the promotion of mutual recognition of international obligations, the dissemination of ideas (crossfertilization) across the different jurisdictions and legal systems, an increase in the authority and legitimacy of the specific judicial decisions, and the creation of a framework of collective judicial deliberation concerning a common set of problems . In any case, the judicial dialogue presupposes the existence of a "deep sense of participation in a global common enterprise of judging” (SLAUGHTER 1999-2000: 1104).

\section{JUdiCIAL DIALOGUE ON HUMAN RIGHTS BETWEEN AMERICA AND EUROPE}

The judicial dialogue between America and Europe on human rights occurs in a context that can be characterized according to the features of constitutional pluralism. Neil MacCormick has pointed out that the constitutional pluralism is identified with a situation where there are several constitutions which do not recognize each other as a source of reciprocal validity, but where there is recognition of their validity. That is, two or more legal systems, considered valid, but which do not see in the others the source of their validity (MACCORMICK 1999).

According to the typology handled by the doctrine, the judicial dialogue between America and Europe on human rights is a horizontal dialogue in which, as such, the respective recognition, the value of persuasion and the respective empathy do not only function as regulative ideals.

I think that the interpretation of the scenario in our current situation is determined, firstly, by the fact that, possibly, too often we have been facing an asymmetric dialogue (MARTIN RETORTILLO BAQUER 2014: 419), where there has been more unidirectionality than bidirectionality (GARCIA ROCA, NOGUEIRA ALCALA, BUSTOS GISBERT 2012: 76; CANO PALOMARES 2015: 50-52), talking more about the influence of the ECHR on the IACHR than about authentic dialogue (GROPPI, LECIS COCCO-ORTU 2014: 192). In any case, recognizing that the dialogue is conditioned by the existence of different social realities, the truth is that we can identify some areas where we can speak of homogeneity, while in others we should speak of differences (GARCIA ROCA, NOGUEIRA ALCALA, BUSTOS GISBERT 2012: $79 \mathrm{ff}$.). Thus, among the similarities, reference should be made to: a) the similarity of the judgment parameters, consisting of the basic elements of the speech of rights and of their international protection gestated within the constitutionalism; b) the recourse to the same judicial criteria and principles of decision, such as the principle of proportionality, effective protection, evolutionary interpretation, or democratic principle; c) the identity of the immediate object of judgment, from a similarity of the facts and the conflicts which originates recourse to judicial protection; d) the similarity of protection proceedings; finally, e) the use of the same argument, based on similar strategies of justification. As regards the differences, these have been pointed out: a) textual differences between the normative reference documents (European Convention 
and American Convention); b) structural differences of both procedures; c) differences in legal and political contexts; d) discursive differences, constituted for example by a greater presence of constitutional discourse in the inter-American system, from the recognized relevance to the control of conventionality of law and the implementation of remedial measures.

Within this framework of mutual recognition both courts, in effect, have sometimes taken the argument generated across the Atlantic in making their own reasoning. Without being exhaustive, we can recall some examples. The IACHR, in Advisory Opinion (OC-5/85) of 13 November 1985 on journalists compulsory joining a professional association, conducted a comparative analysis of Article 13 of the American Convention with Article 10 of the European Convention for the protection of Human Rights and Fundamental Freedoms and Article 19 of the International Covenant on Civil and Political Rights, which made them conclude that "the guarantees of freedom of expression contained in the American Convention were designed to be most generous and to reduce to the minimum the restrictions on the free flow of ideas". Likewise, the IACHR noted that the references to other systems, could not be taken as a basis for the rights' more restrictive regulations than those provided by the interAmerican system itself: "In truth, it is often useful, as the Court has just done, to compare the American Convention with the provisions of other international instruments as a means to highlight particular aspects of the regulation of a particular right, but this method could never be used to incorporate to the Convention restrictions that are not grounded in its text, though they are present in any other international treaty". Thus the IACHR interpreted the art. 29.b of the Convention so that "if in the same situation the American Convention and another international treaty can be applied, the most favorable norm to the human person must prevail. If the Convention itself states that its regulations have no restrictive effect on other international instruments, even fewer restrictions than in those other instruments, but not in the Convention, can be applied to limit the exercise of the rights and freedoms recognized by it”. In the same advisory opinion -and in relation to the concept of public order-, the IACHR explicitly endorsed the opinion of the European Commission of Human Rights that, in its interpretation of the Preamble of the European Convention, stated that "the purpose of the High Contracting Parties when approving the Convention was not to grant reciprocal rights and obligations in order to meet their national interests but ... to establish a common public order of the free democracies of Europe with the aim of safeguarding their common heritage of political traditions, ideals, freedom and the rule of law"9

Moreover, in the judgment of the case Herrera Ulloa v. Costa Rica, on July 2, 2004, the IACHR when setting its doctrine on the place of freedom of expression in a democratic society, again referred to the jurisprudence of the ECHR, when in the case Ivcher Bronstein ${ }^{10}$ said: "freedom of expression constitutes one of the essential pillars of a democratic society and a fundamental condition for its progress and for the personal

\footnotetext{
${ }^{9}$ Austria vs. Italy, Application No.788/60, European Yearbook of Human Rights, vol.4, (1961), p. 138.

${ }^{10}$ Judicial sentence, 6 February 2001. Serie C No. 74.
} 
development of each individual. This freedom must not only be guaranteed with regard to the dissemination of information or ideas that are favorably received or regarded as inoffensive or indifferent but also with regard to those that offend, shock or disturb the state or any sector of the population. Such are the demands of pluralism, tolerance and broadmindedness without which there is no democratic society. [...] This means that [...] any formality, condition, restriction or sanction imposed in this area must be proportionate to the legitimate aim pursued” (par. 152). On this occasion, the IACHR also assumed the references on the issue of the African Commission on Human and Peoples' Rights and the Human Rights Committee of the United Nations. Similarly, in paragraph 170, the Court assumed the jurisprudence of the ECtHR in relation to the concept of judicial impartiality: "The European Court has stated that impartiality has both subjective and objective aspects, namely: First, the court must lack, in a subjective way, personal prejudice. Second, it must also be impartial from an objective viewpoint, that is, it must offer sufficient guarantees so that there is no legitimate doubt about it. Under the objective analysis, it must be determined whether, apart from the personal behavior of judges, there are ascertainable facts which may raise doubts about their impartiality. In this regard, even appearances may be of some importance. What is at stake is the confidence which the courts must inspire in citizens in a democratic society, especially in the sides of the case" 11 .

Similarly, the ECtHR has taken arguments drawn from the jurisprudence of the IACHR. Thus, in the judgment of the case Timurtas c. Turkey, on June 13, 2000, in reference to forced disappearances, and linking them with the right to life, the ECtHR noted "The Inter-American Court has on several occasions pronounced that forced disappearances frequently involve the violation of the right to life. In the inter-American system, a violation of the right to life as a consequence of a forced disappearance can be proved in two different ways. Firstly, it may be established that the facts of the case at hand are consistent with an existing pattern of disappearances in which the victim is killed. Secondly, the facts of an isolated incident of a fatal forced disappearance may be proved on their own, independently of a context of an official pattern of disappearances. Both methods are used to establish State control over the victim's fate which, in conjunction with the passage of time, leads to the conclusion of a violation of the right to life" ${ }^{\prime 2}$. And in the case Akdivar et al. v. Turkey, on September 16, 1996, the ECHR referred to the doctrine of the Court concerning the duty of exhaustion of domestic appeals, and especially the case Velasquez Rodriguez.

In short, and as recalled by Lech Garlicki (GARLICKI 2013: $56 \mathrm{ff}$ ), there are three situations in which the jurisprudence of the IACHR is included in the arguments of the ECtHR. Firstly, in those cases where the ECtHR wants to show their knowledge of international law ("window-dressing-approach"). Secondly, in cases where the ECtHR makes the difference with solutions previously adopted by the IACHR, based on textual or interpretive differences. Thirdly, we find cases in which the reference to the

\footnotetext{
${ }^{11}$ Case Pabla KY v. Finlad, 26 June 2004, para. 27.

${ }^{12}$ In this case, the references to the jurisprudence of IACHR are explicit (Caso Velásquez Rodríguez, 29 July 1988, Serie C no. 4, § 157; Caso Godínez Cruz, 20 January 1989, Serie C no. 5, § 165; Caso Blake, 24 January de 1998, § 66; Caso Fairén Garbi Solís Corrales, 15 March 1989, Serie C no. 6, § 150).
} 
inter-American system has a function of legitimation: "Whenever the Strasbourg Court wants to say something new, and, in particular, whenever it decides to depart from its own case-law or/and from the established practice of several Member-States, it may need to provide a particularly strong justification of such jurisprudential change. An indication that a similar problem has already been addressed and solved in a similar manner within another system of international human rights protection may considerably assist the argumentation of the Strasbourg Court” (GARLICKI 2013: 58). The existence of interdependent and global legal goods, such as rights, justifies the correlative existence of a shared argument.

\section{JUDICIAL DIALOGUE AND MODEL OF LAW}

Any reflection on the future of the dialogue between the Inter-American and the European human rights courts and their consequences ought to take into account the conditions thereof. Thus, two features should be highlighted: its horizontal nature and its voluntary nature. We are in the presence of two regional systems of human rights protection among which there is not hierarchical order. In this sense, any communication between them should be understood as a communication between legal systems (or legal universes) that assume the importance of "looking around" (GARLICKI 2013: 58).

Horizontality leads to voluntariness. No one (no authority or norm) requires judges in Strasbourg to be attentive to the jurisprudence of San José (Costa Rica), and vice versa. So we might wonder why the judicial dialogue occurs in this case, what are the reasons or basis. A wide explanation of the benefits of judicial dialogue or, if preferred, of the communication between judges and courts has to do with the application of Condorcet's Jury Theorem to this topic. According to this theorem, as the participants in a deliberative process aiming at making a decision increase, the chances of reaching a correct answer increase. Thus communication between courts and observing the sense of decisions taken by most courts may be a factor to consider when making the best decision (POSNER, SUNSTEIN 2006: 131 ff.; EDELMAN 2002: 327 ff).

It is true that in the present case we do not find strictly the reasons which, according to De Vergottini, are behind the appeal to the judge-made law of other systems: the failure of the constitutional text, the adoption of a new Constitution or a thorough review, the entailment to certain legal systems, to a legal-cultural area which is not left behind the institutional remoteness, the influence of the constitutional model followed by the constituent or the belonging to the same linguistic-cultural area (VERGOTTINI 2010: 188 ff.).

Therefore, another explanation is needed based on the requirements and consequences. In any case, so that there is judicial dialogue, firstly there must be a sense of community in relation to certain normative contents. Indeed, external judgments should not be cited just to demonstrate knowledge of other jurisprudence. The dialogue 
-and this seems like a logical requirement- is only possible when there is a shared language. And that shared language has to do both with a self-understanding of the judge, as participating in a global joint venture, and with the existence of this community around certain contents, that after all are those of the rights; community which, to exist, must be the result of overcoming the distinction between judges who “give” and judges who only “receive” (L’HEREUX-DUBE 1988: 17).

Regarding the existence of this community of contents, in Europe we know well the difficulties of identifying them, and the normative implications thereof. I mean the notion of "common constitutional tradition", included in the Charter of Fundamental Rights of the European Union ${ }^{13}$. In any case, it seems that the importance of cultural diversity (and, perhaps the "environmental" one) will be inversely proportional to the importance of the core of that community of contents.

I think that the question of the universality of rights is presented today as an unfinished problem from both descriptive and prescriptive point of view. That is, the discussion about which rights are universal and which should be, is far from closed ${ }^{14}$. I think that the most realistic (even honest from the intellectual point of view) but also most demanding from the moral and political point of view is to present the issue in problematic terms. I introduce this point to raise the issue that the dialogue does not need to be presented as a perfect dialogue leading to full identification with the other's position. I think that however much you want to talk about a "Euro-American human rights system” (GARCIA ROCA, NOGUEIRA ALCALA, BUSTOS GISBERT 2012: 99), or present the ECtHR as a kind of "world court of human rights" (SLAUGHTER 1999-2000: 110), since its jurisprudence has been cited by South Africa, Zimbabwe or the IACHR, we must be aware that if the political and social context in which the ECtHR and the IACHR operate is different -and this background has some influence on legal interpretation in general-, perceptions about the best way to recognize rights does not need to be matched in full.

In any case, beyond the difficulties in identifying the coincidences, the horizontal and voluntary nature of the dialogue necessarily leads to stress the importance of judicial comity (SLAUGHTER 1991:1 ff.) of reciprocal recognition and the persuasive dimensions of dialogue. In this regard, it has been said that certain aspects of judicial comity linked to the horizontal judicial dialogue can be highlighted (SLAUGHTER 1999-2000: 112 ff.). Firstly, the recognition of the court is not derived from the fact that this is an organ of a foreign state; what is recognized in that body is its capacity and ability to resolve disputes interpreting and applying the law honestly and competently. Secondly, the capacity of judicial bodies to share strategies employed in resolving disputes and conflicts is recognized. Dialogue therefore involves mutual

13 As known, Title VII of the Charter includes the "GENERAL PROVISIONS GOVERNING THE INTERPRETATION AND APPLICATION OF THE CHARTER". The article 52.4 states "In so far as this Charter recognizes fundamental rights as they result from the constitutional traditions common to the Member States, those rights shall be interpreted in harmony with those traditions”. I have referred to this issue in ANSUATEGUI (2014: 241-259).

${ }^{14}$ I have referred to this issue in ANSUATEGUI (2013b: 73-122). 
recognition of prestige. For Lucio Pegoraro, prestige "could constitute the essential postulate but perhaps not enough" of communication between systems. It is the essential postulate when dialogue is horizontal. Indeed, where we find a vertical dialogue, the foreign argument is used ratione imperii, it is used because it is required to, in the same manner as in the national law the Constitution applies. But in the case of horizontal dialogue, external law is used because they want to do so and not because they must (PEGORARO 2013: 63). So, Anne-Marie Slauhgter claimed a positive comity, understood as an overcoming of mere recognition: the positive comity would be an element of impulse of dialogue (SLAUGHTER 2004: 250 ff.).

In addition, there is an awareness of the importance of the protection of rights and the role of judges in this regard. I think that all this generates dynamics that allow us to speak of a certain "globalization" of jurisdiction. I am not referring to the institutionalization of a global jurisdiction, which could be a good example of the "paradox of globalization" according to which, we need more governance at global and regional level, but at the same time we do not want the centralization of decisionmaking power and coercive authority away from subjects who are called to be governed (SLAUGHTER 2004: 8). Rather, I am thinking about what Julie Allard and Antoine Garapon have called a "commerce des juges" understood as an informal forum for exchanges that do not respond to a specific and predefined structure, but which is located in most cases beyond the institutional mechanisms (ALLARD, GARAPON 2005: 11).

That is, the judicial dialogue generates and presupposes an idea of community. A community based on persuasion and authority of arguments, rather than on the imposition of institutional authority. Neither the jurisprudence of the IACHR nor that of the ECtHR have formal authority to make their arguments mandatory, not even taken into account beyond their territorial scope. What makes them valuable is their argumentative weight, their persuasive authority (GLENN 1987: 262 ff.). What the judge in Strasbourg is searching when resorting to the jurisprudence of San José, and vice versa, is to give their decision more authority relying on the rationality of the arguments developed on the other side of the Atlantic. Here decisions are not taken into account because of their imperium, but because of their iurisdictio (ALLARD, GARAPON 2005: $57 \mathrm{ff}$.), or their auctoritas. Indeed, what matters is not their enforceability, but the applicability of the arguments to the specific case, so that the decision itself is presented with a higher density in its acceptability. It seems clear that openness to judicial dialogue involves overcoming the theory of syllogistic application of the law from a closed system of sources and a corresponding recognition of a greater role of the judge in identifying normative materials that will support the decision, emphasizing an activist dimension of the judge ${ }^{15}$.

In short, the judicial dialogue on human rights, and in particular that between America and Europe, seems to have consequences that go beyond its strictly judicial

${ }^{15}$ So does GROPPI (2011: 205). 
nature and that affect a general understanding of the law. It is true that this dialogue has been enhanced by the relevance of the judicial protection of human rights in the international arena. Indeed, regional systems for the protection of rights, at least so it is in the Inter-American and the Europe cases, end in a tribunal or court. This is already an expression of the importance of the judicial function in guaranteeing rights, in a dynamic that could be interpreted as the result of a translation of some of the logic of constitutionalism at the supranational level ${ }^{16}$. Indeed, since international courts take center stage in practice, we must be aware that the problem of the legitimacy of their decision increases in importance. But also the judge's position is enhanced by the selfunderstanding they have of themselves: they are not inserted in any state structure, do not represent the interests of any government or administration; they claim their autonomy and will be recognized in the framework of the dialogue depending on the argumentative rationality and power of their decisions.

The judicial dialogue contributes to an exchange where it is possible to think of an improvement of argumentative quality since we are no longer in the presence of a monologue, but in a scenario on which the actors can take as a reference the arguments of others. But, in addition, that argumentative community expands its effects beyond the mere exchange of arguments regarding rights. No wonder that, indeed, we are facing some effects that not only have to do with a certain flexibility or deformalization of the system of sources. It is not difficult to suspect that given the centrality of the rights in those systems where they are protected (or pretend to be), a dialogue on the rights may end up being a dialogue on the best form of social organization. The dialogue invites us to stress the argumentative dimension of law. While it is true that the interpretation of the rules must be attentive to the context, it is also true that a universal understanding of rights -which go beyond the regional interpretations- implies the recognition of the validity of the arguments in favor of rights beyond where they are developed. From this point of view, the judicial dialogue can be understood as a requirement of the universality of rights. It implies a positive assessment of "look beyond"; a "look beyond" operating from the moment that there is a "common understanding of the language of rights” (L’HEREUX-DUBE 1988: 24).

Thus, the judicial dialogue on rights transcends in its meaning and effects to the existence of a particular resource in the hands of judges who can use when making the decision for the concrete case. On the contrary, it is an important instrument in the internationalization of rights and their universalization, whose demands go beyond the existence of some international texts. The judicial dialogue contributes to creating a common language and, through the flow of information ${ }^{17}$, promotes the articulation of

\footnotetext{
${ }^{16}$ In this sense, Sabino CASSESE has referred to the reproduction of the contramajoritarian objection in the global law in CASSESE (2009: 103-105). A. Von BOGDANDY and I. VENZKE have referred to the problem of the democratic justification of the decisions of the international courts in BOGDANDY and VENZKE (2013: 83 ff.).

${ }^{17}$ H. P. GLENN believes that "the constituent element of every human community is the information and that there could not be more solid materials or autonomous criteria for collective identity than information." Thus, "the epistemic community is simply a community based on the information, without other explicit or implicit foundations”, in GLENN (2007: 198, 201).
} 
an “epistemic community” (GLENN 2011: 87-92) in which it might be possible to speak of a shared culture -at least judicial- of rights in the framework of a transnational legal community. The judicial nature of the dialogue, its persuasive and voluntary nature are elements to consider when reformulating some traditional keys of understanding the legal world.

In short, the judicial dialogue invites us to see the law otherwise. Openness to other sources outside the system makes that the representations we use to understand the legal system no longer have much to do with a pyramid (Kelsen) but rather with a vault (Pérez Luño) with a network (Ost and Van de Kerchove), or with a novel written by several hands (Dworkin). The result of the development of the judicial dialogue on rights is not so much a formal international legal system, structured according to the traditional principle of hierarchy, but a global community of judges who, networking (SLAUGHTER 2004: 65 ff.), articulate a community aware of its responsibility in building global legal system in which the requirements of the universality of rights may find an optimal environment for their realization. 


\section{REFERENCES}

AA.VV. (2005) “A Conversation between U.S. Supreme Court Justices (The relevance of foreign legal materials in U.S. constitutional cases: A conversation between Justice Antonin Scalia and Justice Stephen Breyer)”, International Journal of Constitutional Law, n. 3 (4).

ACKERMAN, B. (1997) “The Rise of World Constitutionalism”, Virginia Law Review, 83. http://dx.doi.org/10.2307/1073748

ALLARD, J. y GARAPON, A. (2005) Les juges dans la mondialisation. La nouvelle revolution du droit. Paris: Éditions du Seuil et La République des Idées.

ANSUATEGUI ROIG, F. J. (2013a) Razón y voluntad en el Estado de Derecho. Un enfoque filosófico-jurídico. Madrid: Dykinson.

ANSUATEGUI ROIG, F. J. (2013b) "La cuestión de la universalidad de los derechos: de las intuiciones a los problemas”, in PECES-BARBA, G., FERNANDEZ, E., DE ASIS, R., ANSUATEGUI, F. J., FERNANDEZ LIESA, C., (dirs.), Historia de los derechos fundamentales. Siglo XX, tomo IV, vol. IV. Madrid: Dykinson.

ANSUATEGUI ROIG, F. J. (2014) "Derechos fundamentales y "Tradiciones Constitucionales Comunes” en la aplicación del Derecho Europeo”, in Barranco, M. C., Celador, O., Vacas, F. (coords.), Perspectivas actuales en la aplicación del Derecho. Madrid: Dykinson.

BUSTOS GISBERT, R., (2012), "XV proposiciones generales para una teoría de los diálogos judiciales”, Revista Española de Derecho Constitucional, nº 95.

CASSESE, S. (2009) I Tribunali di Babele. I giudici alla ricerca di un nuovo ordine globale. Roma: Donzelli.

CANO PALOMARES, G. (2015) “Diálogo entre jurisdicciones supranacionales de derechos humanos: el Tribunal Europeo de Derechos Humanos y la Corte Interamericana de Derechos Humanos", in REVENGA DANCHEZ, M., CUENCA GOMEZ, P. (eds.), El tiempo de los derechos. Los derechos humanos en el siglo XXI. Madrid: Dykinson.

DE CABO MARTIN, C. (2014) Pensamiento crítico, constitucionalismo crítico. Madrid: Trotta.

DE VERGOTTINI, G. (2010) Más allá del diálogo entre tribunales. Comparación y relación entre jurisdicciones. Cizur Menor: Thomson-Reuters-CívitasAranzadi. 
DE VERGOTTINI, G. (2013) “El diálogo entre tribunales”, in FERRER MACGREGOR, E., HERRERA GARCIA, A. (coords.), Diálogo jurisprudencial en derechos humanos entre Tribunales Constitucionales y Cortes Internacionales. Valencia: Tirant lo Blanch.

EDELMAN, P. H. (2002) “On legal interpretations of the Condorcet Jury Theorem”, Journal of Legal Studies, 31. http://dx.doi. org/10.1086/340409

FERRARESE, M. R. (2006) Diritto sconfinato. Inventiva giuridica e spazi nel mondo globale. Bari: Laterza,

GALGANO, F., (2005) La globalizzazione nello specchio del diritto, Bologna, Il Mulino, Bologna.

GARCIA ROCA, J., NOGUEIRA ALCALA, H., BUSTOS GISBERT, R., (2012) “La comunicación entre ambos sistemas y las características del diálogo", in GARCIA ROCA, J., FERNANDEZ, P. A., SANTOLAYA, P., CANOSA, R., (eds.), El diálogo entre los Sistemas Europeo y Americano de Derechos Humanos. Cizur Menor: Thomson Reuters.

GARLICKI, L., (2013) "Universalism v Regionalism? The role of the supranational judicial dialogue", in GARCIA ROCA, J., FERNANDEZ, P. A., SANTOLAYA, P., CANOSA, R., (eds.), El diálogo entre los Sistemas Europeo y Americano de Derechos Humanos. Valencia: Tirant lo Blanch.

GLENN, H. P. (1987) “Persuasive Authority”, McGill Law Journal, vol. 32, nº 2.

GLENN H. P. (2007) “Identidad, ciudadanía y tradiciones jurídicas”, in DE JULIOS CAMPUZANO, A. (ed.), Ciudadanía y Derecho en la era de la globalización. Madrid: Dykinson.

GLENN, H. P. (2011) Tradizioni giuridiche nel mondo. La sostenibilità della diferenza. Bologna:Il Mulino.

GROPPI, T. (2011) “Bottom up Globalization? Il ricorso a precedenti stranieri da parte delle Corti costituzionali”, Quaderni Costituzionali, a. XXXI, n. 1.

GROPPI, T. and LECIS COCCO-ORTU, A. M. (2014) “Las referencias recíprocas entre el Tribunal Europea y la Corte Interamericana de Derechos Humanos: ¿de la influencia al diálogo?”, Revista de Derecho Político, UNED, nº 91.

HIRSCHL, R. (2004) Towards Juristocracy. The Origins and Consequences of the New Constitutionalism. Cambridge: Harvard University Press.

KRAMER, L. (2004) The People Themselves. Popular Constitutionalism and Judicial Review. New York: Oxford University Press.

L'HEREUX-DUBE, C. (1988) “The importance of Dialogue: Globalization and the International Impact of the Rehnquist Court”, Tulsa Law Journal, 34.

MACCORMICK, N. (1999) Questioning Sovereignty. Law, State and Practical Reasoning in the European Commonwealth. Oxford: Oxford University Press. http://dx.doi.org/10.1093/acprof: oso/9780198268765.001.0001 
MARTIN RETORTILLO BAQUER, L. (2014) “El diálogo Estrasburgo-San José sobre derechos humanos”, Revista Española de Derecho Constitucional, nº 101.

PAUL, J. R. (1991) “Comity in International Law”, Harvard International Law Review, $31,1$.

PEGORARO, L. (2013) "Trasplantes, injertos, diálogos. Jurisprudencia y doctrina frente a los retos del Derecho Comparado”, in FERRER MAC-GREGOR, E., HERRERA GARCIA, A. (coords.), Diálogo jurisprudencial en derechos humanos entre Tribunales Constitucionales y Cortes Internacionales. Valencia: Tirant lo Blanch.

POSNER, E. A. and SUNSTEIN, C. R. (2006) "The Law of other States”, Stanford Law Review, 59, 1.

RODOTÀ, S. (2014) El derecho a tener derechos. Madrid: Trotta.

RUIZ MIGUEL, A. (ed.) (2014) Entre Estado y Cosmópolis. Derecho y justicia en un mundo global. Madrid: Trotta.

SLAUGHTER, A. M. (1994) “A Tipology of Transjudicial Communication”, Richmond Law Review, 29.

SLAUGHTER, A. M. (1999-2000) “Judicial Globalization”, Virginia Journal of International Law, 40.

SLAUGHTER, A. M. (2004) A New Global Order. Princeton: Princeton University Press.

TRIBE, L. H. (2004) "Lawrence v. Texas: The Fundamental Right That Dare Not Speak Its Name”, Harvard Law Review, 117. http://dx.doi. org/10.2307/4093306

TWINING, W. (2000) Globalization and Legal Theory. London: Butterworths.

TWINING, W. (2003) Derecho y globalización. Bogotá: Siglo del Hombre Editores.

Von BOGDANDY, A. and I. VENZKE (2013) “¿En nombre de quién? Un estudio sobre la autoridad política de los tribunales internacionales y su justificación democrática”, in FERRER MAC-GREGOR, E., HERRERA GARCIA, A. (coords.), Diálogo jurisprudencial en derechos humanos entre Tribunales Constitucionales y Cortes Internacionales. Valencia: Tirant lo Blanch.

ZAGREBELSKY, G. (2008a) La legge e la sua giustizia, Bologna. Bologna: Il Mulino.

ZAGREBELSKY, G. (2008b) "El juez constitucional en el siglo XXI", Revista Iberoamericana de Derecho Procesal Constitucional, $\mathrm{n}^{\circ} 10$.

ZAGREBELSKY, G. (2013), “Constitucionalismo”, Derechos y Libertades, nº 29. 